\title{
Clinical, economic and organizational impact of pharmacist interventions on injectable antineoplastic prescriptions: a prospective observational study
}

Céline Zecchini $^{1^{*}}$ (D), Thi-Ha Vo ${ }^{1,2,3}$, Sébastien Chanoine ${ }^{1,2,4}$, Marion Lepelley ${ }^{5}$, Mathieu Laramas ${ }^{6}$, Aude Lemoigne ${ }^{1}$, Benoit Allenet ${ }^{1,2,4}$, Isabelle Federspiel ${ }^{1}$ and Pierrick Bedouch ${ }^{1,2,4}$

\begin{abstract}
Background: Pharmacists play a key role in ensuring the safe use of injectable antineoplastics, which are considered as high-alert medications. Pharmaceutical analysis of injectable antineoplastic prescriptions aims to detect and prevent drug related problems by proposing pharmacist interventions (PI). The impact of this activity for patients, healthcare facilities and other health professionals is not completely known. This study aimed at describing the clinical, economic, and organizational impacts of Pls performed by pharmacists in a chemotherapy preparation unit.

Methods: A prospective 10-week study was conducted on PIs involving injectable antineoplastic prescriptions. Each PI was assessed by one of the four multidisciplinary expert committees using a multidimensional tool with three independent dimensions: clinical, economic and organizational. An ancillary quantitative evaluation of drug cost savings was conducted.

Results: Overall, 185 patients were included (mean age: $63.5 \pm 13.7$ years; $54.1 \%$ were male) and 237 Pls concerning $10.1 \%$ prescriptions were recorded. Twenty one PIs (8.9\%) had major clinical impact (ie: prevented hospitalization or permanent disability), 49 PIs (20.7\%) had moderate clinical impact (ie: prevented harm that would have required further monitoring/treatment), 62 Pls (26.2\%) had minor clinical impact, 95 Pls (40.0\%) had no clinical impact, and 9 PIs (3.8\%) had a negative clinical impact. For one PI (0.4\%) the clinical impact was not determined due to insufficient information. Regarding organizational impact, 67.5\% Pls had a positive impact on patient management from the healthcare providers' perspective. A positive economic impact was observed for 105 PIs (44.3\%), leading to a saving in direct drug costs of 15,096 €; 38 Pls (16.0\%) had a negative economic impact, increasing the direct drug cost by $11,878 €$. Overall cost saving was $3218 €$.
\end{abstract}

Conclusions: Pls are associated with positive clinical, economic and organizational impacts. This study confirms the benefit of pharmacist analysis of injectable antineoplastic prescriptions for patient safety with an overall benefit to the healthcare system.

Keywords: Pharmaceutical analysis, Chemotherapy, Onco-hematology, Pharmacist intervention

\footnotetext{
* Correspondence: zecchini.celine@hotmail.fr

${ }^{1}$ Centre Hospitalo-Universitaire Grenoble Alpes, Pôle Pharmacie, F-38000

Grenoble, France

Full list of author information is available at the end of the article
}

(c) The Author(s). 2020 Open Access This article is distributed under the terms of the Creative Commons Attribution 4.0 International License (http://creativecommons.org/licenses/by/4.0/), which permits unrestricted use, distribution, and reproduction in any medium, provided you give appropriate credit to the original author(s) and the source, provide a link to the Creative Commons license, and indicate if changes were made. The Creative Commons Public Domain Dedication waiver (http://creativecommons.org/publicdomain/zero/1.0/) applies to the data made available in this article, unless otherwise stated. 


\section{Background}

Antineoplastic drugs are among the therapeutic classes the most involved in drug related death due to their narrow therapeutic index, their high level of toxicity and the frailty of treated patients [1, 2]. Considered as highrisk medications, they require expertise from prescription to administration. Many actions are undertaken by pharmacists to ensure the safe management of injectable antineoplastics: centralized reconstitution, computerization, and strict prescription protocols. It is recognized that pharmacists play a crucial role in the safe use of antineoplastic drugs [3]. However, despite these security measures, there is always a residual risk of error, justifying the requirement for pharmaceutical analysis of injectable antineoplastic prescriptions.

In a hospital, the Chemotherapy Preparation Unit (CPU) aims at ensuring the safety of the preparation of injectable antineoplastic drugs under the supervision of a pharmacist. This centralized service can implement the systematic pharmaceutical analysis of injectable antineoplastic prescriptions to detect Drug Related Problems (DRPs), and to carry out Pharmacist Interventions (PIs) in collaboration with prescribers [3, 4]. A DRP is defined as an event or circumstance involving drug therapy that actually or potentially interferes with desired health outcomes [5]. A PI was defined as any action initiated by a pharmacist that directly resulted in a change in a patient's therapeutic management $[6,7]$. If accepted, a PI leads to the modification of patient's therapeutic management [6].

Such modifications may have clinical consequences for patients: in the most severe cases PIs can prevent hospitalization for chemotherapy toxicity, permanent disability such as renal failure, or paresthesia, especially by detecting dosage problems or contraindications [810]. In others cases PIs can improve quality of life, patient satisfaction and adherence with counseling [11]. Taking into account the high direct cost of injectable antineoplastics PIs may have economic impact with cost savings: by dosage adjustments or by drug waste minimization with rounding of drug dosages and selection of the most convenient vial size [12]. PIs can also generate cost avoidance due to the prevention of adverse drug events: according to a study, the mean cost avoidance generated by a PI was $166 €[13,14]$. PIs may have also organizational impacts: pharmacists can engage actions to improve the quality of care process from the perspective of healthcare providers to optimize preparation and administration workflow $[15,16]$.

The French Society of Clinical Pharmacy (SFPC) developed and validated a multidimensional tool for assessing the whole impact of PIs, named CLEO (CLinical, Economic, and Organizational) (Fig. 1) [17, 18]. The CLEO tool includes three independent dimensions to evaluate clinical, economic and organizational impact of PIs to describe the whole impact of PI. The clinical dimension focuses on impact related to the patient's well-being from the patient's perspective: averted damages, improved quality of life, and improved adherence. The economic dimension assesses the immediate impact of the PI on the current costs of therapy from the institution's perspective. The organizational dimension evaluates the impact on the process of care, focusing on the view of the health care professionals: reduced time expenditures, decreased work load, improved work place safety, and simplified collaborations. This tool was also translated and validated a the German version [19].

Other studies performed have evaluated clinical and economic impact of PIs, but to date, no oncohaematology studies have described the impact of PIs using a multidimensional approach, taking into account clinical, economic and organizational dimensions.

This study aims at describing the clinical, economic, and organizational impacts of PIs performed by pharmacists in the CPU of a French University Hospital.

\section{Methods}

\section{Setting}

A 10-week observational study in the CPU of the 2000bed Grenoble Alpes University Hospital (France) was conducted. About 40,000 injectable antineoplastic preparations are produced per year.

A Computerized Provider Order Entry (CPOE) system is used for the prescription of injectable antineoplastics. Prescriptions are made by senior physicians or medicine residents according to standardized protocols that have been previously validated by both pharmacists and physicians. These protocols include: drugs, doses, administration modalities (route, infusion time, solvent), and required premedication. The protocol can concern the prescription of only one injectable antineoplastic or a combination of injectable antineoplastics, for one or more days. When the prescription has been electronically signed, it's automatically transmitted in the software module for pharmacist analysis and preparation.

The prescription is analyzed at the CPU by a senior pharmacist or a trained pharmacy resident prior to administration. For each new prescription, pharmaceutical analysis includes: adequacy of the prescription with the treatment determined during a multidisciplinary cancer board, conformity of the prescribed protocol with the diagnosis and guidelines, doses, and appropriate patient's characteristics. Pharmacists access the patient's medical history through the hospital's electronic medical record system. For prescription renewal, pharmacists verified: the patient's pathophysiological data, cycle duration and number of courses, the previous prescription (drug, dose reduction, comment, and biological data if necessary). 


\section{Clinical impact}

\begin{tabular}{|l|l|l|}
\hline Score & Impact & $\begin{array}{l}\text { Definition: The clinical impact is evaluated according to the most likelv case } \\
\text { expected, not the worst / best case }\end{array}$ \\
\hline -1C & Negative & $\begin{array}{l}\text { The PI can lead to adverse outcomes on clinical status, knowledge, satisfaction, patient } \\
\text { adherence and/or quality of life of the patient. }\end{array}$ \\
\hline OC & Null & $\begin{array}{l}\text { The PI can have no influence on the patient regarding the clinical status, knowledge, } \\
\text { satisfaction, patient adherence and or quality of life of the patient. }\end{array}$ \\
\hline 1C & Minor & $\begin{array}{l}\text { The PI can improve knowledge, satisfaction, medication adherence and/or quality of } \\
\text { life OR the PI can prevent harm that does not require monitoring/treatment. }\end{array}$ \\
\hline 2C & Moderate & $\begin{array}{l}\text { The PI can prevent harm that requires further monitoring/treatment, but does not lead } \\
\text { to or does not extend a hospital stay. }\end{array}$ \\
\hline 3C & Major & $\begin{array}{l}\text { The PI can prevent harm which causes or lengthens a hospital stay OR causes } \\
\text { permanent disability or handicap. }\end{array}$ \\
\hline 4C & Avoids Fatality & $\begin{array}{l}\text { The PI can prevent an accident that potentially causes the need for intensive care or } \\
\text { death of the patient. }\end{array}$ \\
\hline UND & Undetermined & The available information does not allow to evaluate clinical impact. \\
\hline - The clinical impact is evaluated in terms of the benefit to the patient. \\
- Harm: alteration of physical and mental capacities arising from an accident or illness. \\
- $\quad \begin{array}{l}\text { Quality of life: physical function (autonomy, physical abilities, capacity to perform the tasks of daily life etc.), } \\
\text { psychological (anxiety, depression, emotions etc.), social (relative to family environment, friends or professional } \\
\text { contacts, engaging in personal relationships, participation in social and leisure activities etc.) and somatic } \\
\text { (symptoms related to the disease). } \\
\text { - Monitoring: monitoring clinically relevant (physiological or psychological) variables, and/or biological } \\
\text { parameters. }\end{array}$ \\
- Treatment: changing therapy or adding an additional medical / surgical treatment. \\
\hline
\end{tabular}

\section{Economic impact}

\begin{tabular}{|c|c|c|}
\hline Score & Impact & Definition \\
\hline$-1 \mathrm{E}$ & Increase in cost & The PI increases the cost of the drug treatment. \\
\hline $\mathbf{0 E}$ & No change & The PI does not change the cost of drug treatment. \\
\hline $1 \mathbf{E}$ & Decrease in cost & The PI cuts the cost of drug treatment. \\
\hline UND & Undetermined & The available information does not allow to evaluate economic impact. \\
\hline \multicolumn{3}{|c|}{$\begin{array}{l}\text { - The cost of drug therapy contains two main elements: } \\
\text { o The cost of the drugs } \\
\text { o The cost of monitoring drug therapy (e.g., clinical monitoring, kinetics, biological monitoring etc.). } \\
\text { - The cost of drug therapy is based on the financial cost for the hospital. }\end{array}$} \\
\hline
\end{tabular}

\section{Organizational impact}

\begin{tabular}{|l|l|l|}
\hline Score & Impact & Definition \\
\hline $\mathbf{- 1 O}$ & Negative & The PI reduces the quality of care. \\
\hline $\mathbf{0 O}$ & Null & The PI does not change the quality of care. \\
\hline $\mathbf{1 O}$ & Positive & The PI increases the quality of care. \\
\hline UND & Undetermined & The available information does not allow to evaluate organizational impact. \\
\hline $\begin{array}{l}\text { - The organizational impact is coded in terms of the overall impact on the quality of the care process from the } \\
\text { perspective of the health care providers (e.g.,time saving; improved security, knowledge or job satisfaction for } \\
\text { nursing staff; facilitating tasks or teamwork, continuity of care etc.) }\end{array}$ \\
\hline
\end{tabular}

Fig. 1 The CLEO too

The CPOE automatically calculates the body surface area and doses.

When a DRP is identified, the pharmacist (senior or resident) of the CPU calls the medical staff to propose a PI. Finally, when the PI has been discussed with the medical staff, a preparation sheet is sent to pharmacy technicians to prepare chemotherapies.

\section{Data collection}

All consecutive PIs concerning injectable chemotherapy prescriptions in inpatients units (medical oncology and hematology) and outpatient units (medical oncology including thoracic and gastro-intestinal cancer, hematology, radiotherapy) were collected, leading to 237 PIs relating to 185 patients over ten weeks.
PIs were retrospectively recorded using the electronic medical record system, generating a information report including: patients' characteristics (sex, age, weight, height and body surface area), medical history, cancer drugs and cancer protocols used, a description of the DRP and PI according to the classification of the SFPC, and whether or not it was accepted by the physician [7]. These anonymized reports were provided to expert panels for assessment.

\section{Assessment of the impact of pharmaceutical interventions}

Using the CLEO tool, the clinical, economic and organizational consequences of each PI was assessed by consensus in one of four multidisciplinary expert panels 
(medical oncology/radiotherapy, hematology, hepatogastroenterology, and pneumology) [17]. Each panel consisted of four people: a specialist physician, a pharmacovigilance expert, a clinical pharmacist and a CPU pharmacist. The CLEO tool has three independent dimensions: clinical impact of the PI from the patient's perspective, economic impact of the PI from the hospital's perspective, and organizational impact of the PI from the healthcare provider's perspective (Fig. 1). Each dimension of the CLEO tool has several numeric levels, with both negative, zero, positive and values, and an open level "non-determined". The CLEO tool and 12 examples of assessments were provided to the expert panel before any PI evaluation. After the presentation of each PI by the meeting moderator, each expert independently scored clinical, economic and organizational impacts of the PI prior to discussion to reach an expert consensus.

\section{Economic analysis}

Quantifying cost savings related to direct antineoplastic costs was determined by a complementary evaluation to the CLEO tool. Cost savings were determined by listing all PIs with a positive economic impact according to the expert panel assessment using the CLEO tool (e.g. trastuzumab $6 \mathrm{mg} / \mathrm{kg}$ instead of trastuzumab $8 \mathrm{mg} / \mathrm{kg}$ ). Similarly, increased costs were calculated from all PIs having a negative economic impact according to the CLEO tool (e.g. trastuzumab $6 \mathrm{mg} / \mathrm{kg}$ instead of trastuzumab $2 \mathrm{mg} /$ $\mathrm{kg}$ ). This quantitative evaluation of savings or additional costs was conducted from the hospital's perspective. It took into account the cost of injectable antineoplastics including value added tax but excluded the cost of solvents, diluents, and sterile medical devices used for preparation. Costs were calculated only for the treatment course concerned by the accepted PI, assuming that a PI has an impact only on one course. Cost savings were calculated based on the real costs of the PI accepted by the prescriber.

\section{Statistical analysis}

Descriptive data are presented with frequency and percentage or as means with standard deviation (SD). All statistical analyses were performed using Microsoft Office Excel 2007.

\section{Results}

Over the 10-week period, three pharmacists and two pharmacy residents of the CPU analyzed 1989 prescriptions of injectable antineoplastic involving 5284 preparations for 759 patients in inpatient units or outpatient units. Among them, 200 prescriptions (10.1\%) relating to 185 patients had DRPs leading to 237 PIs. Patients concerned by DRPs were of mean age $63.5 \pm 13.7$ years, mainly male and had solid tumors (Table 1).
Table 1 Characteristics of patients with DRP $(n=185)$

\begin{tabular}{|c|c|}
\hline Patients characteristics & n (\%) \\
\hline Age, mean (SD) & $63.5(13.7)$ \\
\hline Sex (male) & $100(54.1)$ \\
\hline \multicolumn{2}{|l|}{ Diagnosis } \\
\hline Solid tumor & $150(81.1)$ \\
\hline Breast Cancer & $26(14.1)$ \\
\hline Colorectal cancer & $26(14.1)$ \\
\hline Non-small cell lung cancer & $22(11.9)$ \\
\hline Head and neck cancer & $21(11.4)$ \\
\hline Ovarian cancer & $10(5.4)$ \\
\hline Cancer of the pancreas & $8(4.3)$ \\
\hline Neuroendocrine cancer & $8(4.3)$ \\
\hline Bladder cancer & $5(2.7)$ \\
\hline Small cell lung cancer & $5(2.7)$ \\
\hline Cervical cancer & $4(2.2)$ \\
\hline Oesophageal cancer & $4(2.2)$ \\
\hline Glioma & $2(1.1)$ \\
\hline Sarcoma & $2(1.1)$ \\
\hline Thymus carcinoma & $2(1.1)$ \\
\hline Anal cancer & $1(0.5)$ \\
\hline Astrocytoma & $1(0.5)$ \\
\hline Biliary cancer & $1(0.5)$ \\
\hline Gastric cancer & $1(0.5)$ \\
\hline Prostate cancer & $1(0.5)$ \\
\hline Hematologic disease & 35 (18.9) \\
\hline Non Hodgkin lymphoma & $11(6.0)$ \\
\hline Multiple myeloma & $8(4.3)$ \\
\hline Acute leukemia & $7(3.9)$ \\
\hline Hodgkin lymphoma & $3(1.6)$ \\
\hline Myelomonocytic leukemia & $2(1.1)$ \\
\hline Chronic lymphocytic leukemia & $1(0.5)$ \\
\hline Glanzmann thrombasthenia & $1(0.5)$ \\
\hline Hairy cell leukemia & $1(0.5)$ \\
\hline Idiopathic thrombocytopenic purpura & $1(0.5)$ \\
\hline
\end{tabular}

Drug-related problems AND nature of the pharmacist interventions

DRPs mainly concerned dosages: $41.4 \%(n=98)$ were a supra-therapeutic dosage and $15.2 \% \quad(n=36)$ a subtherapeutic dosage (Table 2). The causes of supratherapeutic dosages were mainly failure to make dose reductions due to toxicity and overestimations of patient's weight. Sub-therapeutic dosages were often related to a failure to update of serum creatinine level in the dose calculation of Carboplatin and also errors in patient's weight. In $12.2 \%$ of cases $(n=29)$, a parameter was missing for analyzing the prescription; in such cases 
Table 2 Types of DRPs and PIs

\begin{tabular}{|c|c|}
\hline Drug related problems & n (\%) \\
\hline Supratherapeutic dosage & $98(41.4)$ \\
\hline Subtherapeutic dosage & $36(15.2)$ \\
\hline Drug monitoring & $29(12.2)$ \\
\hline Non-conformity to guidelines & $26(11.0)$ \\
\hline Untreated indication & $23(9.7)$ \\
\hline Inappropriate timing of administration & $9(3.8)$ \\
\hline Drug without indication & $7(3.0)$ \\
\hline Contra-indication & $4(1.7)$ \\
\hline Improper administration & $2(0.8)$ \\
\hline Adverse drug reaction & $1(0.4)$ \\
\hline Non-conformity of the drug choice compared to the Formulary & $1(0.4)$ \\
\hline Treatment not received & $1(0.4)$ \\
\hline \multicolumn{2}{|l|}{ Interventions } \\
\hline Dose adjustment & $125(52.7)$ \\
\hline Drug switch & $36(15.2)$ \\
\hline Addition of a new drug & $23(9.7)$ \\
\hline Drug monitoring & $22(9.3)$ \\
\hline Drug discontinuation & $19(8.0)$ \\
\hline Administration mode optimization & $12(5.1)$ \\
\hline Total & $237(100)$ \\
\hline
\end{tabular}

monitoring or an update of monitoring (e.g. creatinine clearance) was requested to the prescriber. For $11.0 \%$ $(n=26)$, the DRP was related to non-conformity with the guidelines, e.g. the prescribed therapeutic protocol did not correspond to the correct protocol, the previously prescribed chemotherapy regimen or the regimen recommended for the patient at the last multidisciplinary cancer board. Untreated indications concerned 9.7\% of PIs $(n=23)$; this problem being due to the lack of prescription for a patient or the absence of a drug in the prescribed protocol. The PIs were: dose adjustment (52.7\%), drug switch request (15.2\%), drug addition (9.7\%), drug monitoring (9.3\%), drug discontinuation (8.0\%), and administration mode optimization (5.1\%) (Table 2).

The main injectable antineoplastics involved in DRP were: Carboplatin $(n=38)$, Cisplatin $(n=36)$ and Fluorouracil $(n=28)$ (Fig. 2).

Most PIs $(n=179 ; 75.5 \%)$ were accepted by prescribers (refusal rate: $24.5 \%$ ).

\section{CLINICAL, ECONOMIC AND ORGANIZATIONAL IMPACT OF PIs}

The multidimensional impact was determined for 237 PIs using the CLEO tool.

Overall, 21 PIs (8.9\%) were considered to have had a major clinical impact, which could prevent hospitalization, the prolongation of hospitalization or permanent disability. Experts determined that neurological, hematological, renal, gastrointestinal and skin toxicities were avoided, but no PI was considered to have avoided a lethal accident. The list of these 21 PIs were summarized in Table 3. The majority of these PIs required dose adjustment. All PIs with major clinical impact were accepted by the prescribers. Experts considered that 49 PIs (20.7\%) had a moderate clinical impact, which could prevent harm that would have required further monitoring or treatment, 62 PIs (26.2\%) had a minor clinical impact that would have required further monitoring/treatment. While 95 PIs (40.0\%) had no clinical impact, the panels considered 9 PIs out of 237 (3.8\%) as potentially harmful; these PIs were all rejected by prescribers. For one PI (0.4\%) the clinical impact was not determined because the committee had insufficient available information (Fig. 3).

Regarding organizational impact, 165 PIs (67.5\%) were evaluated as having a positive impact on the quality of patient management, and $71(30.0 \%)$ and 6 PIs (2.5\%) as having a null or unfavorable impact, respectively. Fortyone PIs were considered as having no clinical or economic impact but only a favorable organizational impact. These PIs most often concerned a date or hospitalization unit errors. These changes were requested in order to facilitate the work of healthcare providers in charge of the patient, allowing them to see the prescription at the 


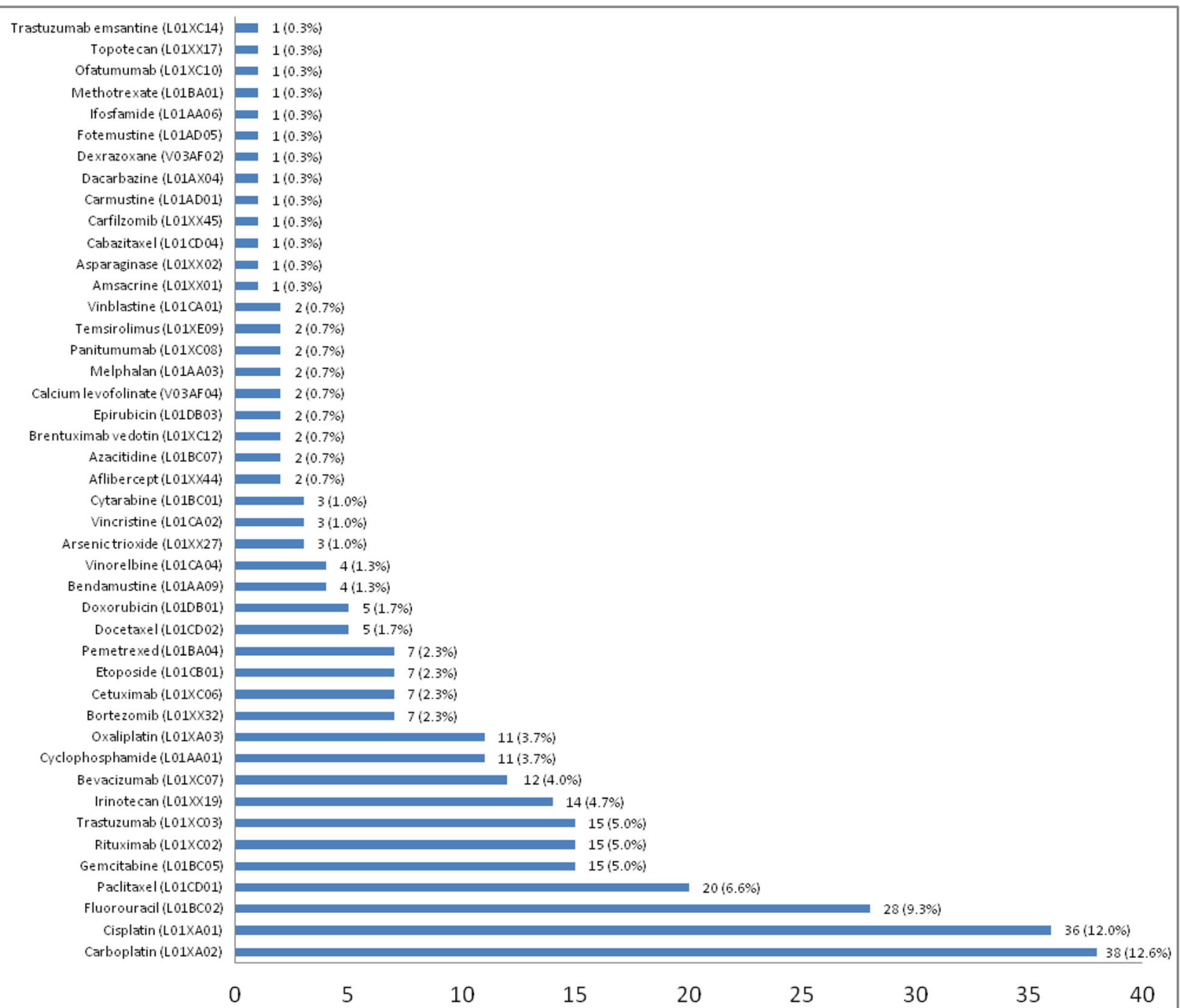

Fig. 2 Anatomical Therapeutic Chemical (ATC) classification of chemotherapy drugs involved in Drug Related Problems

right date for the correct care unit and authorizing them to validate electronically the administration of the chemotherapy.

Concerning economic aspects, according to the expert assessment using the CLEO tool, 105 PIs (44.3\%) were assessed as having a positive impact (resulted in reduced cost of antineoplastic drugs), 94 PIs (39.7\%) had null economic impact and 38 PIs (16.0\%) a negative economic impact (increasing the cost of antineoplastic drugs). PIs accepted by prescribers with negative economic impact increased the direct drug costs by 11,878 $€$ and PIs accepted by prescribers with positive economic impact represented a saving of 15,096 € (Table 4).

Through pharmaceutical analysis, the final cost saving was of $3218 €$ over the study period. Drug cost saving for a year would thus be $16,731 €$ for our hospital. For
PIs accepted by prescribers and having a positive economic impact, the average saving per accepted PI was $181 \pm 451 €$, ranging from $0 €$ to $2019 €$ (median: $5.3 €$; IQR: $15.9 €)$. These PIs were related to dose adjustments $(n=61)$, drug switch requests $(n=11)$ and drug discontinuations $(n=10)$. For PIs accepted by prescribers having a negative economic impact, the average additional cost per accepted PI was $439 \pm 835 €$, ranging from $0 €$ to $3262 €$ (median: $21.9 €$; IQR: $507.2 €$ ). These PIs were related to dose adjustments $(n=15)$, drug additions $(\mathrm{n}=$ $6)$, drug switch requests $(n=5)$ and administration mode optimization $(\mathrm{n}=1)$.

PIs with a major, moderate and minor clinical impact predominantly had a positive economic impact with respectively 90.5, 69.4 and 50.0\% positive economic impact (Fig. 4). No PI with major clinical impact had a negative 
Table 3 Description of PIs with a major clinical impact $(n=21)$

\begin{tabular}{|c|c|c|c|c|c|c|}
\hline Unit & DRP & Drug(s) & $\mathrm{PI}$ & Description & $\begin{array}{l}\text { Economic } \\
\text { impact }\end{array}$ & $\begin{array}{l}\text { Organizational } \\
\text { impact }\end{array}$ \\
\hline $\begin{array}{l}\text { Hepato- } \\
\text { gastro } \\
\text { enterology } \\
\text { day care } \\
\text { unit }\end{array}$ & $\begin{array}{l}\text { Non conformity } \\
\text { to guidelines }\end{array}$ & Panitumumab & $\begin{array}{l}\text { Drug } \\
\text { switch }\end{array}$ & $\begin{array}{l}\text { Course number 1: Prescription VECTIBIX / } \\
\text { FOLFOX instead of AVASTIN FOLFOX (RAS } \\
\text { analysis in progress) }\end{array}$ & 1 & 0 \\
\hline $\begin{array}{l}\text { Hepato- } \\
\text { gastro } \\
\text { enterology } \\
\text { day care } \\
\text { unit }\end{array}$ & $\begin{array}{l}\text { Non conformity } \\
\text { to guidelines }\end{array}$ & Panitumumab & $\begin{array}{l}\text { Drug } \\
\text { switch }\end{array}$ & $\begin{array}{l}\text { Course number 1: Prescription VECTIBIX / } \\
\text { FOLFOX instead of AVASTIN FOLFOX (RAS } \\
\text { analysis in progress) }\end{array}$ & 1 & 0 \\
\hline $\begin{array}{l}\text { Oncology } \\
\text { day care } \\
\text { unit }\end{array}$ & $\begin{array}{l}\text { Non conformity } \\
\text { to guidelines }\end{array}$ & Gemcitabine & $\begin{array}{l}\text { Drug } \\
\text { discontinuation }\end{array}$ & $\begin{array}{l}\text { Prescription signed and green light given for } \\
\text { gemcitabine but course should be canceled due } \\
\text { to thrombocytopenia }\end{array}$ & 1 & 1 \\
\hline $\begin{array}{l}\text { Radio } \\
\text { therapy } \\
\text { day care } \\
\text { unit }\end{array}$ & $\begin{array}{l}\text { Non conformity } \\
\text { to guidelines }\end{array}$ & Cisplatin & $\begin{array}{l}\text { Dose } \\
\text { adjustment }\end{array}$ & $\begin{array}{l}\text { Overdose: Prescription cisplatin } 60 \mathrm{mg} / \mathrm{m}^{2} \text { for } 2 \\
\text { days, while the patient should not receive } \\
\text { cisplatin on day } 2\end{array}$ & 1 & 1 \\
\hline $\begin{array}{l}\text { Pneu } \\
\text { mology } \\
\text { day care } \\
\text { unit }\end{array}$ & $\begin{array}{l}\text { Contra } \\
\text { indication }\end{array}$ & Cisplatin & $\begin{array}{l}\text { Drug } \\
\text { discontinuation }\end{array}$ & $\begin{array}{l}\text { Prescription of an adjuvant cisplatin course for a } \\
\text { patient having a clearance of creatinine } 43 \mathrm{ml} / \\
\text { min according to the CKD EPI formula }\end{array}$ & 1 & 1 \\
\hline $\begin{array}{l}\text { Oncology } \\
\text { day care } \\
\text { unit }\end{array}$ & $\begin{array}{l}\text { Untreated } \\
\text { indication }\end{array}$ & Trastuzumab & $\begin{array}{l}\text { Addition of } \\
\text { a new drug }\end{array}$ & $\begin{array}{l}\text { Error in the protocol: missing one line in protocol } \\
\text { on Taxotere Cyclophosphamide Trastuzumab }\end{array}$ & 0 & 1 \\
\hline $\begin{array}{l}\text { Oncology } \\
\text { day care } \\
\text { unit }\end{array}$ & $\begin{array}{l}\text { Untreated } \\
\text { indication }\end{array}$ & Trastuzumab & $\begin{array}{l}\text { Addition of } \\
\text { a new drug }\end{array}$ & $\begin{array}{l}\text { Error in the protocol: missing one line in protocol } \\
\text { on Taxotere Cyclophosphamide Trastuzumab }\end{array}$ & 0 & 1 \\
\hline $\begin{array}{l}\text { Hepato- } \\
\text { gastro } \\
\text { enterology } \\
\text { day care } \\
\text { unit }\end{array}$ & $\begin{array}{l}\text { Supra- } \\
\text { therapeutic } \\
\text { dosage }\end{array}$ & $\begin{array}{l}\text { Fluorouracile } \\
\text { Oxaliplatin }\end{array}$ & $\begin{array}{l}\text { Dose } \\
\text { adjustment }\end{array}$ & $\begin{array}{l}\text { Reductions of } 50 \% \text { of in } 5 \text { fluorouracil ( } 5 F U \text { ) and } \\
\text { of } 80 \% \text { in oxaliplatin omitted in a patient with } \\
\text { toxic } \\
\text { ileitis to } 5 \text { FU in his medical records }\end{array}$ & 1 & 0 \\
\hline $\begin{array}{l}\text { Oncology } \\
\text { day care } \\
\text { unit }\end{array}$ & $\begin{array}{l}\text { Supra- } \\
\text { therapeutic } \\
\text { dosage }\end{array}$ & Cetuximab & $\begin{array}{l}\text { Dose } \\
\text { adjustment }\end{array}$ & $\begin{array}{l}\text { Expected reduction cetuximab } 200 \mathrm{mg} / \mathrm{m}^{2} \\
\text { instead of } 500 \mathrm{mg} / \mathrm{m}^{2} \text { not appliedToxicity } \\
\text { during previous treatments: folliculitis, xerosis }\end{array}$ & 1 & 1 \\
\hline $\begin{array}{l}\text { Oncology } \\
\text { day care } \\
\text { unit }\end{array}$ & $\begin{array}{l}\text { Supra- } \\
\text { therapeutic } \\
\text { dosage }\end{array}$ & $\begin{array}{l}\text { Cyclophosphamide } \\
\text { Doxorubicine } \\
\text { Cisplatine }\end{array}$ & $\begin{array}{l}\text { Dose } \\
\text { adjustment }\end{array}$ & $\begin{array}{l}\text { Expected reductions of } 80 \% \text { for } \\
\text { Cyclophosphamide and doxorubicin and of } 66 \% \\
\text { for cisplatin omitted. During the intercure period: } \\
\text { anemia, thrombocytopenia, non-febrile } \\
\text { agranulocytosis, oedematous decompensation } \\
\text { leading to emergency consultation }\end{array}$ & 1 & 1 \\
\hline $\begin{array}{l}\text { Oncology } \\
\text { day care } \\
\text { unit }\end{array}$ & $\begin{array}{l}\text { Supra- } \\
\text { therapeutic } \\
\text { dosage }\end{array}$ & Irinotecan & $\begin{array}{l}\text { Dose } \\
\text { adjustment }\end{array}$ & $\begin{array}{l}\text { Reduction of } 80 \% \text { for irinotecan omitted } \\
\text { During the intercure period: Hospitalization } \\
\text { for diarrhea during previous course }\end{array}$ & 1 & 1 \\
\hline $\begin{array}{l}\text { Oncology } \\
\text { day care } \\
\text { unit }\end{array}$ & $\begin{array}{l}\text { Supra- } \\
\text { therapeutic } \\
\text { dosage }\end{array}$ & Paclitaxel & $\begin{array}{l}\text { Dose } \\
\text { adjustment }\end{array}$ & $\begin{array}{l}\text { Expected reduction to } 80 \% \text { paclitaxel not } \\
\text { appliedToxicity: paresthesia of hands and feet } \\
\text { prior to paclitaxel }\end{array}$ & 1 & 1 \\
\hline $\begin{array}{l}\text { Oncology } \\
\text { day care } \\
\text { unit }\end{array}$ & $\begin{array}{l}\text { Supra- } \\
\text { therapeutic } \\
\text { dosage }\end{array}$ & Cabazitaxel & $\begin{array}{l}\text { Dose } \\
\text { adjustment }\end{array}$ & $\begin{array}{l}\text { Expected reduction to } 80 \% \text { for carbazitaxel } \\
\text { Hospitalization during previous course for } \\
\text { deterioration in general condition and nausea }\end{array}$ & 1 & 1 \\
\hline $\begin{array}{l}\text { Oncology } \\
\text { day care } \\
\text { unit }\end{array}$ & $\begin{array}{l}\text { Supra- } \\
\text { therapeutic } \\
\text { dosage }\end{array}$ & Paclitaxel & $\begin{array}{l}\text { Dose } \\
\text { adjustment }\end{array}$ & $\begin{array}{l}\text { Expected reduction of } 80 \% \text { for paclitaxel omitted } \\
\text { Toxicity: Feet paresthesia prior to paclitaxel }\end{array}$ & 1 & 1 \\
\hline $\begin{array}{l}\text { Oncology } \\
\text { day care } \\
\text { unit }\end{array}$ & $\begin{array}{l}\text { Supra- } \\
\text { therapeutic } \\
\text { dosage }\end{array}$ & Paclitaxel & $\begin{array}{l}\text { Dose } \\
\text { adjustment }\end{array}$ & $\begin{array}{l}\text { Expected reduction of } 80 \% \text { paclitaxel not } \\
\text { appliedToxicity: Hands and feet paresthesia prior } \\
\text { to paclitaxel }\end{array}$ & 1 & 1 \\
\hline $\begin{array}{l}\text { Oncology } \\
\text { day care } \\
\text { unit }\end{array}$ & $\begin{array}{l}\text { Supra- } \\
\text { therapeutic } \\
\text { dosage }\end{array}$ & Paclitaxel & $\begin{array}{l}\text { Dose } \\
\text { adjustment }\end{array}$ & $\begin{array}{l}\text { Expected reduction of } 80 \% \text { for paclitaxel not } \\
\text { applied } \\
\text { Toxicity during previous treatments: Neuropathy }\end{array}$ & 1 & 1 \\
\hline
\end{tabular}


Table 3 Description of PIs with a major clinical impact $(n=21)$ (Continued)

\begin{tabular}{|c|c|c|c|c|c|c|}
\hline Unit & DRP & Drug(s) & $\mathrm{Pl}$ & Description & $\begin{array}{l}\text { Economic } \\
\text { impact }\end{array}$ & $\begin{array}{l}\text { Organizational } \\
\text { impact }\end{array}$ \\
\hline $\begin{array}{l}\text { Oncology } \\
\text { day care } \\
\text { unit }\end{array}$ & $\begin{array}{l}\text { Supra- } \\
\text { therapeutic } \\
\text { dosage }\end{array}$ & Docetaxel & $\begin{array}{l}\text { Dose } \\
\text { adjustment }\end{array}$ & $\begin{array}{l}\text { Expected reduction of } 66 \% \text { for not applied } \\
\text { Toxicity during intercure: Edema of the lower } \\
\text { limbs }\end{array}$ & 1 & 1 \\
\hline $\begin{array}{l}\text { Oncology } \\
\text { day care } \\
\text { unit }\end{array}$ & $\begin{array}{l}\text { Supra- } \\
\text { therapeutic } \\
\text { dosage }\end{array}$ & Vinorelbine & $\begin{array}{l}\text { Dose } \\
\text { adjustment }\end{array}$ & $\begin{array}{l}\text { Prescription of weekly navelbine at dosage of } 25 \\
\mathrm{mg} / \mathrm{m}^{2} \text { Medical history: Neutropenia grade IV } \\
\text { with a weekly navelbine protocol }\end{array}$ & 1 & 1 \\
\hline $\begin{array}{l}\text { Oncology } \\
\text { day care } \\
\text { unit }\end{array}$ & $\begin{array}{l}\text { Supra- } \\
\text { therapeutic } \\
\text { dosage }\end{array}$ & Vinorelbine & $\begin{array}{l}\text { Dose } \\
\text { adjustment }\end{array}$ & $\begin{array}{l}\text { Expected reduction of } 80 \% \text { for navelbine } \\
\text { Toxicity during intercure: Hospitalization for } \\
\text { general condition alteration and febrile peak }\end{array}$ & 1 & 1 \\
\hline $\begin{array}{l}\text { Oncology } \\
\text { day care } \\
\text { unit }\end{array}$ & $\begin{array}{l}\text { Supra- } \\
\text { therapeutic } \\
\text { dosage }\end{array}$ & Gemcitabine & $\begin{array}{l}\text { Dose } \\
\text { adjustment }\end{array}$ & $\begin{array}{l}\text { Expected reduction of } 80 \% \text { for gemcitabine not } \\
\text { applied } \\
\text { Toxicity during previous treatment: Febrile } \\
\text { neutropenia }\end{array}$ & 1 & 1 \\
\hline $\begin{array}{l}\text { Oncology } \\
\text { day care } \\
\text { unit }\end{array}$ & $\begin{array}{l}\text { Supra- } \\
\text { therapeutic } \\
\text { dosage }\end{array}$ & $\begin{array}{l}\text { Cisplatin } \\
\text { Fluorouracile }\end{array}$ & $\begin{array}{l}\text { Dose } \\
\text { adjustment }\end{array}$ & $\begin{array}{l}\text { Course number 1: expected reductions because } \\
\text { of asthenia and undernutrition by } 80 \% \text { for } \\
\text { cisplatin and fluorouracile not applied }\end{array}$ & 1 & 1 \\
\hline
\end{tabular}

economic impact. Seventy-three PIs had no clinical and economic impact, nevertheless 42 of them (57.5\%) had a positive organizational impact (Fig. 4). Finally, few PIs (12.7\%) had no impact on the 3 dimensions.

\section{Discussion}

This study shows that DRPs are commonly encountered in injectable antineoplastic prescriptions. PIs related to DRPs significantly improve prescriptions in terms of clinical, economic and organizational dimensions: $55.8 \%$ of PIs had a positive clinical impact, $67.5 \%$ PIs had a positive impact on patient management from the healthcare providers' perspective and a cost saving of $3218 €$ on drugs was realized over the study period.

\section{Findings}

Previous studies have reported PIs as being needed for 1.5 to $27.6 \%$ of injectable antineoplastic prescriptions [20-24]. This wide range can be explained by organizational differences: in a center without computerized prescriptions, $27.6 \%$ of prescriptions required a PI [24]. A DRP rate of $3.0 \%$ was found in an establishment in which prescriptions were based on standardized pre-printed prescriptions and a listing of protocols [22]. Recent studies in settings with CPOE found a PI rate lower than $2 \%[20,21]$. In our study, the PI rate of $10.1 \%$ was quite high despite computerized prescriptions and use of protocols. A large proportion of prescriptions established by residents in medicine and the lack of update of creatinine values in the CPOE system may explain this finding.

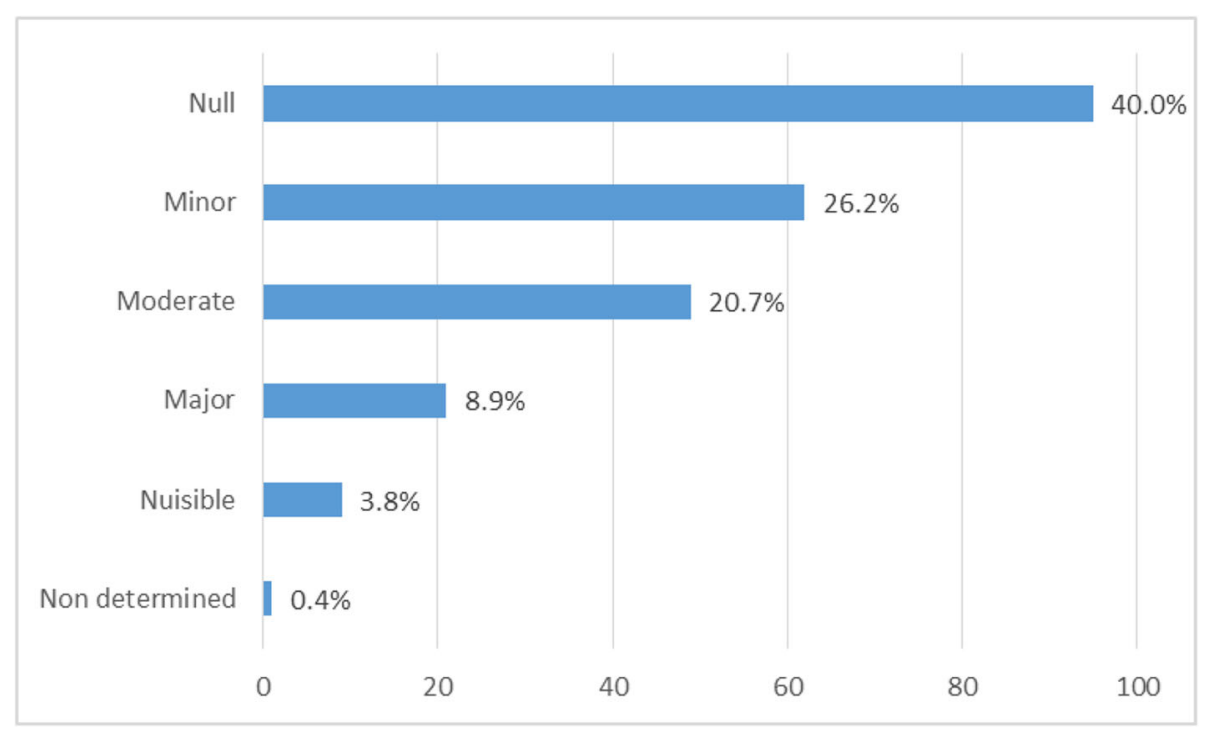

Fig. 3 Clinical impact of Pharmacist's Interventions 


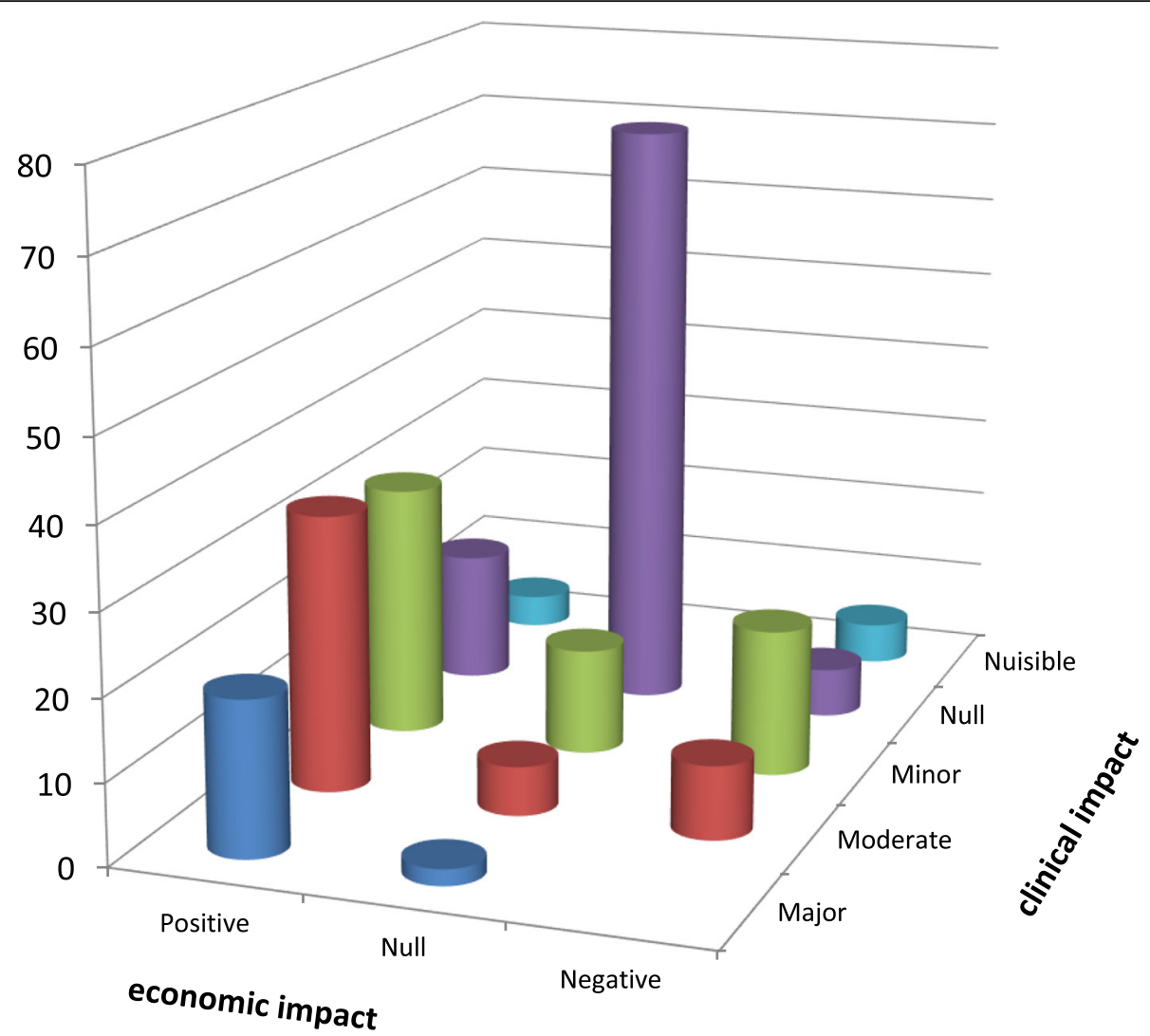

Fig. 4 Combination of clinical and economic impact levels of PIs

Our results confirm those of previous studies which showed that overdosages and under-dosages are the most frequently encountered problems [20, 21, 24]. Consequently, in more than half of cases, PIs requested a dose adjustment. Monitoring problems is the third most commonly encountered DRP, mainly related to creatinine value updates required for platinum compounds. In agreement with previous studies, most PIs were formulated for two drugs: Carboplatin $(n=39)$ and Cisplatin $(n=36)$ [22]. This result can be explained by the risk of renal toxicity of platinum compounds requiring regular dose adjustment or leading to contra-indication.

In our study, PIs were accepted by senior physicians and medicine residents in $75.5 \%$ of the cases. This

Table 4 Classification of Economic Impact and Quantifying of Cost Saving

\begin{tabular}{lll}
\hline Economic impact & Number of interventions (\%) & Costs \\
\hline -1: Negative & $38(16.0)$ & $11,878 €$ \\
0: Null & $94(39.7)$ & $0 €$ \\
+ 1: Positive & $105(44.3)$ & $15,096 €$ \\
Total benefit & & $\mathbf{3 2 1 8} €$ \\
\hline
\end{tabular}

acceptance rate is close to that usually observed in cancerology and in others areas of clinical pharmacy $[21,25]$.

This study shows that the pharmaceutical analysis of injectable antineoplastic prescriptions has a positive clinical impact: $55.8 \%$ of PIs were considered to have a positive clinical impact. Our results are in accordance with the literature, even if the use of different tools does not allow us to directly compare our results with the previous studies. Knez et al. found that $48 \%$ of PIs involving injectable antineoplastic prescriptions were clinically very significant, another study in a large chemotherapy preparation unit reported that $50.4 \%$ of PIs were considered to be clinically significant $[8,23]$.

In our study, no PI was considered to have avoided a potentially lethal effect for the patient, while some other studies have reported PIs performed by pharmacists in a CPU that potentially avoided patient death $[21,23,26]$. In these studies, PIs with life-saving impact were essentially related to overdose prescription problems of 3-to 50-fold the theoretical doses or cases of co-prescription. During the period studied in our hospital there was no case of such large overdosage as that reported elsewhere, possibly due to safer 
procedures including computerized prescriptions and standardized protocols.

Our choice of using the CLEO tool enabled us to identify PIs with a negative clinical impact. Nine PIs were considered by the expert panels to have a negative clinical impact. For 5 of them, the inappropriateness of the PI was due to changes in patient's clinical status that had not been saved into the electronic medical record system and therefore was unknown to pharmacists before their intervention.

Our study suggests that the pharmaceutical analysis of injectable antineoplastic prescriptions has a positive economic impact from hospital's perspective by reducing direct drug costs: $44.3 \%$ of PIs decreased the cost of patient's therapeutic management. These results are in accordance with previous studies [27-29]. In a study conducted in another French university hospital, focusing on the pharmaceutical analysis of injectable antineoplastic prescriptions, Nerich et al. found that $31.7 \%$ of PIs reduced direct drug costs [27]. In the same study, it was estimated that 1459 PIs carried out over a one-year period generated a saving of $25,136 €$ from hospital's perspective. In our University Hospital, we estimated that savings would be $16,731 €$ over a year, somewhat less. However, it is difficult to compare results between these two studies, because the cost assessment is based on the purchase prices of injectable antineoplastic drugs, which differs between hospitals and over time. In our study, we assumed that a PI had an economic impact on a single course of chemotherapy, whereas other studies extrapolated the impact of a PI beyond a single course of the drug. Even taking the shortest chronological impact, pharmaceutical analysis of injectable antineoplastics is associated with a positive economic impact [30]. In another French study, the authors estimated that, over a year, chemotherapy-related drug errors could have resulted in an additional 216 days of hospitalization, and cost avoidance related to hospitalization and medication was estimated at $92,907 €$ if these errors had not been detected by pharmaceutical analysis [26].

A majority (67.5\%) of PIs had a positive organizational impact. These PIs included changes in the date of prescription or in the hospital unit, and minimal dose adjustments. They were considered as having a positive organizational impact because the quality of the prescription was improved. For example in our organization, the CPOE automatically propose a date of prescription according to the date of the previous injection. If the next injection must be postponed by many days, the prescriber must manually modify the date proposed. If the date is not modified, the prescription will appear on the date originally planned. Despite the use of CPOE prescription errors remain persistent, this is a well-known problem, including for antineoplastics [31-
33]. To our knowledge no other study took into account the organizational impact of PIs for healthcare providers. However, organizational impact was the most difficult of the three dimensions to assess, because of the many different indicators of care management (time savings, improved security, knowledge, job satisfaction, continuity of care etc.) and the need to take into account the different points of view of the various healthcare professionals (physicians, pharmacists, nurses).

\section{Strength and limitations}

To the best of our knowledge, this is the first study describing the impact of PI for injectable antineoplastic prescriptions in a multidimensional way. Most tools focus on clinical outcomes and/or cost savings. However, some PIs that have no direct clinical or economic impact can benefit for the healthcare practitioners, for example, a PI that improves safety for nurses (e.g., the pharmacist suggests a change in the dosage form such that the nurse does not have to manipulate potentially toxic drugs). The organizational dimension of the CLEO tool aims to detect such effect. One could use all three dimensions, with a three-component code describing the entire impact of a PI.

As the CLEO tool does not quantify savings or additional costs, for the economic evaluation we used a complementary approach limited to the direct costs of drugs. The experts (specialist physicians and pharmacists) determined that, in some cases, neurological, hematological, renal, gastrointestinal and skin toxicities were avoided but the costs of treatments or additional days of hospitalization that would have been needed to manage these adverse drug events were not assessed.

\section{Conclusion}

Pharmaceutical analysis of injectable antineoplastic prescriptions in a CPU is complementary of clinical pharmacy activities performed in oncology and hematology care units. Our study shows that pharmaceutical analysis of injectable antineoplastic prescriptions has clinical, economic and organizational impacts. The involvement of pharmacists reduces medication errors, some of which could have serious consequences for oncology patients due drugs toxicity. In a large hospital the centralization of the pharmaceutical analysis of injectable antineoplastic prescriptions presents additional economic and organizational interests, leading to PIs for dose adjustments, drug switches, or drug discontinuations that reduce the direct costs of drug management. The evaluation of this activity should be regularly conducted to assess the added value of pharmacists in improving quality of care for patients and for healthcare system and could also be used as indicator of pharmacist's performance. 


\section{Abbreviations}

ATC: Anatomical Therapeutic Chemical; CKD EPI: Chronic Kidney Disease EPIdemiology collaboration; CLEO: CLinical, Economic, and Organizational; CPOE: Computerized Provider Order Entry; CPU: Chemotherapy Preparation Unit; DRP: Drug Related Problem; IQR: Interquatile range; PI: Pharmacist Intervention; SD: Standard deviation; SFPC: French Society of Clinical Pharmacy

\section{Acknowledgements}

The authors wish to thank experts of different committees: Lysiane MOLINA, Aurélie DURAND, Anne Claire TOFFART, Sophie LOGEROT, Claire CHAPUIS, Dominique CHARLETY, Magalie BAUDRANT. The authors wish to thank Marjorie DURAND, Marion PAYEN and Marion ALLOUCHERY for collecting the data. We thank Alison FOOTE (Grenoble Alpes University Hospital) for critically editing the manuscript and language corrections.

\section{Authors' informations}

- Céline ZECCHINI: Hospital Pharmacist, PharmD

- Thi-Ha VO: Assistant Professor in Clinical Pharmacy, PhD, PharmD

- Sébastien CHANOINE: Assistant Professor in Clinical Pharmacy, PhD, PharmD

- Marion LEPELLEY: Hospital Pharmacist, PharmD

- Mathieu LARAMAS: Oncologist, MD

- Aude LEMOIGNE: Hospital Pharmacist, PharmD

- Benoît ALLENET: Professor in Clinical Pharmacy, PhD, PharmD

- Isabelle FEDERSPIEL: Hospital Pharmacist, PharmD

- Pierrick BEDOUCH: Professor in Clinical Pharmacy, Head of the Pharmacy

Department at Grenoble University Hospital, PhD, PharmD.

\section{Authors' contributions}

$\mathrm{CZ}$, THV, IF and PB designed the study. MLE, MLA, IF and AL made substantial contributions to the acquisition of data. CZ, THV, SC, IF and PB were major contributors in writing the manuscript. BA revised the manuscript for important intellectual content. All authors read and approved the final manuscript.

\section{Funding}

No sources of funding were used to assist in the preparation of this study.

\section{Availability of data and materials}

The datasets used during the current study are available from the corresponding author on reasonable request.

\section{Ethics approval and consent to participate}

Study ethics approval was obtained from CECIC Rhône-Alpes-Auvergne, Clermont-Ferrand (IRB 5891). The CECIC considering the recommended nature of the control of the prescription of high-alert medications by a hospital pharmacist and the usual character of this practice, did not raise any ethical problem with the publication of this work and judged unnecessary the request of written or verbal consent. The CECIC has allowed accessing and using the data and records described in the study. This decision was made after reviewing our project according to the French Law on Research Involving the Human Person and the Declaration of Helsinki of the World Medical Association.

\section{Consent for publication}

not applicable.

\section{Competing interests}

The authors declare that they have no competing interests.

\section{Author details}

${ }^{1}$ Centre Hospitalo-Universitaire Grenoble Alpes, Pôle Pharmacie, F-38000 Grenoble, France. ${ }^{2}$ CNRS, TIMC-IMAG, UMR5525, F-38000 Grenoble, France. ${ }^{3}$ Pham Ngoc Thạch University of Medicine, Hochiminh V-70000, Vietnam. ${ }^{4}$ University Grenoble Alpes, F-38000 Grenoble, France. ${ }^{5}$ Centre Régional de Pharmacovigilance, F-38000 Grenoble, France. ${ }^{6}$ Centre Hospitalo-Universitaire Grenoble Alpes, Pôle Cancer et maladies du sang, F-38000 Grenoble, France.
Received: 9 August 2019 Accepted: 5 February 2020

Published online: 12 February 2020

\section{References}

1. Juntti-Patinen L, Neuvonen PJ. Drug-related deaths in a university central hospital. Eur J Clin Pharmacol. 2002:58:479-82.

2. Phillips J, Beam S, Brinker A, Holquist C, Honig P, Lee LY, et al. Retrospective analysis of mortalities associated with medication errors. Am J Health-Syst Pharm. 2001;58:1835-41.

3. Sessink PJ, Wittenhorst BC, Anzion RB, Bos RP. Exposure of pharmacy technicians to antineoplastic agents: reevaluation after additional protective measures. Arch Environ Health. 1997;52:240-4.

4. Favier M, Fliche E, Bressolle F. Economic benefit of a centralized reconstitution unit of cytotoxic drugs in isolator. J Oncol Pharm Pract. 1996; 2:182-5.

5. Pharmaceutical Care Network Europe Foundation PCNE Classification for drug-related problems V8.02. 2018. Website https://www.pcne.org Accessed 9 sept 2018.

6. Dooley MJ, Allen KM, Doecke CJ, Galbraith KJ, Taylor GR, Bright J, et al. A prospective multicentre study of pharmacist initiated changes to drug therapy and patient management in acute care government funded hospitals. Br J Clin Pharmacol. 2004;57:513-21.

7. Allenet B, Bedouch P, Rose F-X, Escofier L, Roubille R, Charpiat B, et al. Validation of an instrument for the documentation of clinical pharmacists' interventions. Pharm World Sci. 2006:28:181-8.

8. Knez L, Laaksonen R, Duggan C. Evaluation of clinical interventions made by pharmacists in chemotherapy preparation. Radiol Oncol. 2010;44:249-56.

9. Chew C, Chiang J, Yeoh $\Pi$. Impact of outpatient interventions made at an ambulatory cancer Centre oncology pharmacy in Singapore. J Oncol Pharm Pract. 2015;21:93-101.

10. Farias TF. Aguiar K da S, Rotta I, Belletti KM da S, Carlotto J. Implementing a clinical pharmacy service in hematology. Einstein. 2016;14:384-90.

11. Colombo LRP, Aguiar PM, Lima TM, Storpirtis S. The effects of pharmacist interventions on adult outpatients with cancer: a systematic review. J Clin Pharm Ther. 2017:42:414-24

12. Fasola G, Aprile G, Marini L, Follador A, Mansutti M, Miscoria M. Drug waste minimization as an effective strategy of cost-containment in oncology. BMC Health Serv Res. 2014;14:57.

13. Bates DW, Spell N, Cullen DJ, Burdick E, Laird N, Petersen LA, et al. The costs of adverse drug events in hospitalized patients. Adverse drug events prevention study group. JAMA. 1997;277:307-11.

14. Gallagher J, Byrne S, Woods N, Lynch D, McCarthy S. Cost-outcome description of clinical pharmacist interventions in a university teaching hospital. BMC Health Serv Res. 2014;14:177.

15. Claus B, Pourcq KD, Clottens N, Kruse V, Gemmel P, Vandenbroucke J. The impact of logarithmic dose banding of anticancer drugs on pharmacy compounding efficiency at Ghent University Hospital. Eur J Hosp Pharm Sci Pract. 2018;25:334-6.

16. O'Leary CE, Collins A, Henman MC, King F. Introduction of a dose-banding system for parenteral chemotherapy on a haematology-oncology day ward. J Oncol Pharm Pract. 2019;25:351-61.

17. Vo T.-H. Evaluation of the potential impact of pharmacist interventions: development and validation of the CLEO multidimensional tool. Pharmaceutical sciences. Université Grenoble Alpes. 2015. https://tel. archives-ouvertes.fr/tel-01315619/document Accessed 9 sept 2018.

18. Mongaret C, Quillet P, Vo TH, Aubert L, Fourgeaud M, Michelet-Huot E, et al. Predictive factors for clinically significant pharmacist interventions at hospital admission. Medicine (Baltimore). 2018;97:e9865.

19. Stampfli $D$, Baumgartner $P$, Boeni $F$, Bedouch $P$, Lampert ML, Hersberger KE. Translation and validation of a tool to assess the impact of clinical pharmacists' interventions. Int J Clin Pharm. 2019;41:56-64.

20. Nerich V, Limat S, Demarchi M, Borg C, Rohrlich PS, Deconinck E, et al. Computerized physician order entry of injectable antineoplastic drugs: an epidemiologic study of prescribing medication errors. Int J Med Inf. 2010;79: 699-706.

21. Han J-M, Ah Y-M, Suh SY, Jung S-H, Hahn HJ, Im S-A, et al. Clinical and economic impact of pharmacists' intervention in a large volume chemotherapy preparation unit. Int J Clin Pharm. 2016;38:1124-3.

22. Vantard N, Ranchon F, Schwiertz V, Gourc C, Gauthier N, Guedat M-G, et al. EPICC study: evaluation of pharmaceutical intervention in cancer care. J Clin Pharm Ther. 2015:40:196-203. 
23. Grangeasse L, Juste M, Rose F-X, Roubille R, Chaigneau L, Medjoub M, Larosa F, Bracco-Nolin CH, et al. Computerized and protocolized prescription of chemotherapy, residual iatrogenic risk and pharmaceutical interventions. J Pharm Clin. 2006;25:33-8.

24. Slama C, Jerome J, Jacquot C, Bonan B. Prescription errors with cytotoxic drugs and the inadequacy of existing classifications. Pharm World Sci PWS 2005;27:339-43. 3.

25. Bedouch P, Charpiat B, Conort O, Rose F-X, Escofier L, Juste M, et al. Assessment of clinical pharmacists' interventions in French hospitals: results of a multicenter study. Ann Pharmacother. 2008:42:1095-103.

26. Ranchon F, Salles G, Späth H-M, Schwiertz V, Vantard N, Parat S, et al. Chemotherapeutic errors in hospitalised cancer patients: attributable damage and extra costs. BMC Cancer. 2011;11:478.

27. Nerich V, Borg C, Villanueva C, Thiery-Vuillemin A, Helias P, Rohrlich P-S, et al. Economic impact of prescribing error prevention with computerized physician order entry of injectable antineoplastic drugs. J Oncol Pharm. 2013;19:8-17.

28. Hatoum HT, Hutchinson RA, Witte KW, Newby GP. Evaluation of the contribution of clinical pharmacists: inpatient care and cost reduction. Drug Intell Clin Pharm. 1988;22:252-9.

29. Nesbit TW, Shermock KM, Bobek MB, Capozzi DL, Flores PA, Leonard MC, et al. Implementation and pharmacoeconomic analysis of a clinical staff pharmacist practice model. Am J Health-Syst Pharm. 2001;58:784-90.

30. Rose F-X, Escofier L, Conort O, Charpiat B, Bedouch P, Allenet B, Roubille R, Juste M. Multicentric study of the economic impact of pharmaceutical interventions. Gest Hosp. 2009:490:549-54

31. Nanji KC, Rothschild JM, Salzberg C, Keohane CA, Zigmont K, Devita J, et al. Errors associated with outpatient computerized prescribing systems. J Am Med Inform Assoc JAMIA. 2011;18:767-73.

32. Bedouch P, Tessier A, Baudrant M, Labarere J, Foroni L, Calop J, et al. Computerized physician order entry system combined with on-ward pharmacist: analysis of pharmacists' interventions. J Eval Clin Pract. 2012;18: 911-8.

33. Aita M, Belvedere O, De Carlo E, Deroma L, De Pauli F, Gurrieri L, et al. Chemotherapy prescribing errors: an observational study on the role of information technology and computerized physician order entry systems. BMC Health Serv Res. 2013;13:522.

\section{Publisher's Note}

Springer Nature remains neutral with regard to jurisdictional claims in published maps and institutional affiliations.

Ready to submit your research? Choose BMC and benefit from:

- fast, convenient online submission

- thorough peer review by experienced researchers in your field

- rapid publication on acceptance

- support for research data, including large and complex data types

- gold Open Access which fosters wider collaboration and increased citations

- maximum visibility for your research: over $100 \mathrm{M}$ website views per year

At $\mathrm{BMC}$, research is always in progress.

Learn more biomedcentral.com/submissions 